\title{
14. mednarodni slavistični kongres na Ohridu od 9. do 16. septembra 2008
}

\author{
Silvo Torkar
}

IZVLEČEK: Makedonski slavisti so pet let po ljubljanskem 13. kongresu letos uspešno izpeljali 14. mednarodni slavistični kongres, najbolj reprezentativno srečanje slavistov iz celega sveta. Okrog šeststo udeležencev kongresa se je zbralo na Ohridu, eni od zibelk slovanske pismenosti.

\begin{abstract}
The 14th International Slavic Congress in Ohrid, 9-16 September 2008

ABSTRACT: Five years after the 13th congress held in Ljubljana, Macedonian Slavic specialists hosted the 14th International Slavic Congress, the most prominent conference of Slavic specialists from around the world. Approximately six hundred congress participants gathered in Ohrid, one of the cradles of Slavic literacy.
\end{abstract}

Makedonski slavisti so pet let po ljubljanskem 13. kongresu skupaj z Mednarodnim slavističnim komitejem letos uspešno izpeljali 14. mednarodni slavistični kongres, najbolj reprezentativno srečanje slavistov iz celega sveta. ${ }^{1}$ Okrog šeststo udeležencev kongresa se je zbralo na Ohridu, eni od zibelk slovanske pismenosti.

Kongres je bil za Makedonce prvovrstna priložnost za mednarodno uveljavitev njihove slavistike, jezika in državnosti, zato ni presenetljivo, da so ga podprli predvsem z državnim financiranjem in le malo s sponzorskimi sredstvi. Kongres so pozdravile najvišje osebnosti makedonskega političnega in znanstvenega življenja od predsednika države Branka Crvenkovskega in predsednika vlade Nikola Gruevskega, dveh pokroviteljev kongresa, do predsednika Makedonske akademije znanosti in umetnosti Georgija Stardelova, rektorja Univerze Sv. Cirila in Metoda v Skopju G'org'ija Martinovskega in župana Ohrida Aleksandra Petreskega, odprl in zaprl pa ga je predsednik Mednarodnega slavističnega komiteja akad. Milan G'určinov.

1 Poročila o 11., 12. in 13. mednarodnemem slavističnem kongresu v Bratislavi (1993), Krakovu (1998) in Ljubljani (2003) so prispevali Miran Hladnik (Delo-Književni listi 7.X. 1993), France Novak (Jezikoslovni zapiski 4, 1998) in Alenka Šivic-Dular (Jezikoslovni zapiski 9/2, 2003). 
Tematika 14. MSK je bila sprejeta na zasedanju Predsedstva Mednarodnega slavističnega komiteja v Beogradu junija 2005, objavljena pa je bila med drugim $\mathrm{v}$ Slavistični reviji št. 1 za leto 2006, zajeta je seveda tudi v kongresnem Programu, dostopnem v knjižni in spletni obliki (http://www.msk.edu.mk).

$\mathrm{S}$ področja jezikoslovja je bilo sprejetih osem tematskih sklopov oz. sekcij, s področja literarne vede, kulturologije in folkloristike deset in s področja zgodovine slavistike dva. Prijavljeni referenti so nastopili na t. i. sekcijskih zasedanjih, kjer so imeli po že ustaljenem redu petnajst minut za predstavitev in pet minut za razpravo.

Delo kongresa je potekalo samo prvi dan tudi v plenarni obliki, ko so bili na sporedu trije referati: Trajko Stamatoski iz Makedonije je predstavil Razvoj makedonskega knjižnega jezika, Aleksander M. Moldovan iz Moskve Poti slavistike v sodobnem svetu, Robert Hodel iz Nemčije pa (v ruščini) Ali predstavlja družinski roman posebno zvrst?. Že od prvega dne dalje je delo potekalo v sekcijah (dopoldne od 9.30 do 11.30 in od 12.00 do 14.00, popoldne pa od 17.00 do 19.00).

Najpomembnejša oblika dela kongresa poleg sekcijskih zasedanj so zasedanja tematskih blokov. Teh je bilo na ohridskem kongresu doslej največ, kar 24 (od tega 13 jezikoslovnih), izbrani pa so bili že na zasedanju mednarodnega slavističnega komiteja v Vidmu septembra 2006 (gl. Zapisnik s tega zasedanja, objavljen v Slavistični reviji 2006/3-4). Zasedali so med 17.00 in 19.00 od srede (10. septembra) do petka ter $\mathrm{v}$ nedeljo in ponedeljek (15. septembra).

Organizirani sta bili tudi dve okrogli mizi (od predvidenih treh, sprejetih prav tako v Vidmu): Slovanski svet in Evropa ter Mesto slovanskih jezikov in stanje slavistike $v$ svetu.

Na kongresu so v petek, 12. septembra, zasedale znanstvene komisije pri Mednarodnem slavističnem komiteju. Že od krakovskega kongresa je teh komisij kar 29 , vendar se med seboj precej razlikujejo glede na stopnjo svoje aktivnosti med dvema kongresoma. Aktivnost se meri predvsem z organizacijo znanstvenih srečanj in objavo ustreznih zbornikov. Med najbolj aktivnimi je vsekakor Komisija za slovansko etimologijo, ki ji je doslej predsedoval srbski etimolog Aleksandar Loma, v naslednjem mandatu pa je to vlogo prevzela Alenka Šivic-Dular. V Komisiji za slovansko onomastiko je vlogo predsedujočega prevzela Aleksandra Cieślikowa iz Krakova. Med najbolj aktivne komisije spadajo Komisija za folkloro (predsedujoči Ljubinko Radenković iz Beograda), Komisija za etnolingvistiko (Jerzy Bartmiński iz Lublina), Komisija za leksikologijo in leksikografijo (Margarita Černišova iz Moskve), Komisija za slovansko frazeologijo (Valerij Mokienko iz Sankt-Peterburga), Komisija za Splošnoslovanski lingvistični atlas (Tatjana Vendina iz Moskve), Komisija za slovnična vprašanja slovanskih jezikov (Jarmilo Panevovo iz Prage je zamenjal Predrag Piper iz Novega Sada), Komisija za jezikoslovno bibliografijo (Zofia Rudnik-Karwatowa iz Varšave). V okviru slednje se že vrsto let zbira in objavlja (zadnja leta samo na svetovnem spletu) izčrpna bibliografija jezikoslovnih del (knjig in člankov) v slovanskih jezikih, za slovenski del je vse do letos skrbel Marko Kranjec.

Dne 12. septembra je $\mathrm{v}$ okviru kongresa potekal jubilejni večer ob stoletnici rojstva pesnika Koča Racina z recitalom njegovih pesmi v makedonščini in 
prevodih v druge slovanske jezike. Štirje kongresni večeri (od 19.00 do 20.00) so bili posvečeni promociji izbranih slavističnih publikacij, med njimi Splošnoslovanskega lingvističnega atlasa (OLA) in petzvezkovnega Etimološkega slovarja kašubščine avtorjev W. Borysia in H. Popowske-Taborske.

Udeležencem kongresa je bil na voljo tudi poseben kulturni program - razstava makedonskih noš v Hotelu Belvi, filmski večer makedonskih dokumentarnih filmov in razstava slik in skulptur makedonskega likovnega umetnika Vladimirja Georgievskega.

V okviru kongresa je bila že tradicionalno organizirana tudi razstava slavističnih publikacij vseh držav-udeleženk za obdobje zadnjih pet let. Razstavljene knjige ostanejo makedonskim knjižnicam kot darilo nacionalnih slavističnih komitejev in tako pomembno obogatijo knjižnične fonde države-organizatorice.

V soboto, 13. septembra, je bil dan, namenjen ekskurzijam, medtem ko je predsedstvo Mednarodnega slavističnega komiteja zasedalo na Ohridu. V dopoldanskem času je bila organizirana uradna ekskurzija v mesto Ohrid za vse udeležence kongresa, medtem ko so bile na izbiro še plačljive ekskurzije v samostan Sv. Nauma, samostan Sv. Jovana Bigorskega, Bitolo, daljši ogled kulturno-zgodovinskih spomenikov Ohrida in nočno križarjenje z ladjo po Ohridskem jezeru.

Za prijavljanje, nameščanje $v$ hotelih, prevoze in ekskurzije je skrbela makedonska potovalna agencija VIS POJ. Vsi udeleženci kongresa so prejeli lično torbico s priponko in gradivom, ki je obsegalo knjižno izdajo Програма на конгресот, dva Зборника на резимеа, I том Лингвистика, II том Книжевност, култура, фолклор, историја на славистика, Тематски блокови, debelo knjigo Реферати на македонските слависти за XIV-от меѓународен славистички конгрес во Охрид in lično opremljeno beležnico, vse v znamenju ikone sv. Klimenta Ohridskega.

Dobra stran organizacije ohridskega kongresa je bila, da se je večina dogodkov odvijala v prostorih hotela Metropol, kjer je prebival velik del udeležencev (ostali so bivali še v sosednjem Belviju, bližnjem Univerzitetnem kongresnem centru ter malo bolj oddaljenih hotelih Granit in Gorica). Prve štiri dneve so zaradi izjemno toplega vremena lahko dodobra izrabili tudi vsi ljubitelji kopanja za osvežitev v dokaj čistih vodah Ohridskega jezera.

Delo na kongresu je sicer teklo brez večjih zapletov, čeprav je treba povedati, da organizatorji niso znali vselej zbrati $\mathrm{v}$ isti sekciji tematsko istorodnih referatov in se je marsikdaj zgodilo, da so se znašli skupaj besedotvorna, akcentološka in tekstološka problematika.

Iz Slovenije je bilo deset udeležencev (od 14 prijavljenih), ki so v kongresni številki Slavistične revije objavili 13 razprav (11 jezikoslovnih in 2 literarnovedni).

Metka Furlan (ZRC SAZU) je nastopila v tematskem bloku Aспекты этимологических исследований $\mathrm{z}$ referatom Interna in eksterna rekonstrukcija $v$ slovanski etimologiji.

V okviru prve, dokaj raznorodne sekcije oz. tematskega sklopa so svoje referate predstavili Vanda Babič (Filozofska fakulteta v Ljubljani), Matej Sovič in njegov latinski prevod cerkvenoslovanske slovnice Meletija Smotrickega iz leta 1773, Alenka Šivic-Dular (Filozofska fakulteta v Ljubljani), Tipologija pridevniške skla- 
njatve $v$ arealnem kontekstu (prispevek bo objavljen $\mathrm{v}$ eni izmed prihodnjih številk SRL), Marko Jesenšek (Filozofska fakulteta v Mariboru), Prekmurska publicistika 19. in prve polovice 20. stoletja - med knjižno normo in tradicijo in Irena Orel (Filozofska fakulteta v Ljubljani), Grammatik der Slavischen Sprache in Krain, Kärnten und Steyermark (1808) Jerneja Kopitarja in Primož Trubar. V drugi, dialektološko-etnolingvistični sekciji sta nastopili Vera Smole (Filozofska fakulteta in ZRC SAZU) Geolingvistična predstavitev izbranih frazemov s sestavino roka $v$ slovenskih narečjih in Barbara Ivančič Kutin (ZRC SAZU), Neslovanske besede $v$ bovškem narečnem besedišču. V tretji, onomastični sekciji, sem svoj referat Slovenska zemljepisna imena, nastala iz slovanskih antroponimov podal (v ruščini) samo podpisani Silvo Torkar (ZRC SAZU), ker se Mihaela Koletnik (Filozofska fakulteta v Mariboru) kljub objavi referata $O$ prekmurskih mikrotoponimih kongresa ni udeležila. Tudi v peti sekciji, posvečeni slovničnim vprašanjem slovanskih jezikov, je bil predstavljen samo referat avtoric Ade Vidovič Muha in Aleksandre Derganc (Filozofska fakulteta v Ljubljani), Glagolsko izražanje svojilnosti v slovenščini in ruščini, saj je Andreja Žele (ZRC SAZU) svoj referat Reševanje nekaterih skladenjskih vprašanj $v$ slovenščini glede na razpoložljive teorije in metode sicer objavila, kongresa pa se ni mogla udeležiti. Naposled je v šesti, leksikalno-frazeološki sekciji izostala še Irena Stramljič-Breznik (Filozofska fakulteta v Mariboru), ki je sicer objavila referat Prevzete leksemske prvine in njihova besedotvorna zmožnost $v$ slovenščini. Slovensko literarno vedo je na samem kongresu zastopal Vladimir Osolnik (Filozofska fakulteta v Ljubljani) z referatom Romantični ep in nacionalna identiteta pri Južnih Slovanih, medtem ko je Milena Mileva Blažić (Pedagoška fakulteta v Ljubljani) besedilo svojega prispevka Primerjalna analiza germanskih, romanskih in slovanskih ljudskih pravljic na primeru motiva živalskega ženina in živalske neveste samo objavila, kongresa pa se ni udeležila.

Onomastična sekcija, ki sem ji predsedoval skupaj s švedskim udeležencem Perom Ambrosianijem, je bila ena od manjših. Zbrala je sicer veliko znamenitih imen v publiki, medtem ko najmočnejših slovanskih onomastikov (Poljakov in Čehov) skorajda ni bilo med nastopajočimi. Elena Berezovič je v reviji Voprosy onomastiki leta 2004 poročala o onomastičnih temah na ljubljanskem slavističnem kongresu in ugotovila, da je bilo napovedanih 13 onomastičnih referatov, realno prebranih pa le 8. Na Ohridu je bilo napovedanih 12 , realno prebranih pa 10. Med hujše spodrsljaje organizatorjev vsekakor spada uvrstitev izrazito onomastičnega referata izraelskega udeleženca, sicer dopisnega člana SAZU Wolfa Moskovicha, Slavic-Jewish Interaction in the Shaping of Family Names in the East Slavic Region, v sekcijo za literarno komparativistiko.

Med predavatelji, ki so zbrali največje množice poslušalcev, velja omeniti vsaj Svetlano Tolstoj iz Moskve z referatom Семантическая реконструкция и проблема многозначности праславянского слова, tematski blok o slovanski frazeologiji Valerija Mokienka (Greifswald-Sankt-Peterburg) ter Vladimira Petruhina iz Moskve z referatom Древнерусский пантеон: итоги и перспективы междисииплинарных исследований.

Ob koncu kongresa so Aleksander Duličenko iz Tartuja, Janusz Siatkowski iz Varšave in Genadz Cihun iz Minska podali skupno poročilo o delu jezikoslovnih 
sekcij in tematskih blokov. Ugotovili so, da glede etnogeneze in glotogeneze Slovanov na kongresu ni bilo bistvenih novosti, da je $\mathrm{v}$ znanstveni obtok vstopil zajeten korpus novih cerkvenoslovanskih besedil skupaj z njihovo analizo, da so bili na kongresu prikazani uspehi lingvogeografskih raziskav in pri obdelavi gradiva ponujeni nekateri sintetizirani pristopi, da so bile na kongresu dostojno zastopane etnolingvistične raziskave in je bil predlagan obsežen projekt rekonstrukcije jezikovno-kulturne slike slovanskega sveta; kot nova in perspektivna smer se je pokazalo korpusno jezikoslovje, kot aktualno pa raziskovanje jezikovnih stikov in mešanja jezikov; prvič je bila na kongresu $\mathrm{v}$ tolikšnem obsegu prikazana problematika slovanskih mikrojezikov; kot zelo produktivne so se pokazale raziskave $\mathrm{v}$ slovanski frazeologiji.

Naslednji mednarodni slavistični kongres je po sklepu predsedstva Mednarodnega slavističnega komiteja predviden $\mathrm{v}$ beloruskem Minsku.

Silvo Torkar

Inštitut za slovenski jezik Frana Ramovša ZRC SAZU

Novi trg 2, 1000 Ljubljana

silvot@zrc-sazu.si 